\title{
KONTRIBUSI DAKWAH DALAM MENGANTISIPASI NARKOBA DI KOTA PALOPO
}

\author{
1Masmuddin, ${ }^{2}$ Syahruddin \\ 1,2 Institut Agama Islam Negeri Palopo \\ E-mail: masmuddin@iainpalopo.ac.id
}

\begin{abstract}
This study aims to describe the contribution of da'wah in anticipating drug abuse and trafficking in the city of Palopo. Da'wah referred to in this study is not only from the group of preachers in a professional manner, but all those who always call for virtue and forbidding evil, including those who forbid misuse and distribution of drugs. Data obtained by interview are then analyzed by data reduction and triangulation. The results showed that the propaganda method carried out by the preachers in anticipating drug abuse and distribution is by conducting counseling, lectures through various community groups, especially groups of school children ranging from early age to universities and other social groups.
\end{abstract}

Keywords: Article, Contents, Format

\begin{abstract}
Abstrak
Penelitian ini bertujuan untuk melihat kontribusi dakwah dalam mengantisipasi penyalahgunaan dan pengedaaran narkoba di kota Palopo. Dakwah yang dimaksud dalam penelitian ini bukan saja dari kelompok muballigh secara professional, tetapi semua yang selalu mengajak kepada kebajikan dan melarang kepada kemungkaran, termasuk yang melarang menyalahgunakan dan mengedarkan narkoba. Data yang diperoleh dengan wawancara kemudian dianalisis dengan reduksi data dan triangulasi. Hasil penelitian menunjukkan bahwa metode dakwah yang dilakukan oleh para dai dalam mengantispasi penyalahgunaan dan pengedaran narkoba adalah dengan melakukan penyuluhan, ceramahceramah melalaui berbagai kelompok masyarakat, terutama kelompok anak sekolah mulai dari usia dini sampai kepada perguruan tinggi dan kelompok-kelompok sosial lainnya.
\end{abstract}

Kata Kunci,: Kontribusi Dakwah, Narkoba, Kota Palopo.

\section{PENDAHULUAN}

Negara Indonesia pada umumnya adalah negara yang sedang berkembang. Sebagaimana negara-negara yang sedang berkembang, Indonesia banyak menerima pengaruh yang berasal dari negara sekitarnya, baik itu pengaruh yang sifatnya positif maupun yang bersifat negatif. Dalam meningkatkan taraf hidup masyarakat maka negara berusaha untuk mengikuti perkembangan teknologi yang sudah ada di negara-negara maju, baik itu di bidang pertanian, perindustrian, maupun teknologi pengobatan. Salah satu obat-obatan yang berkhasiat dan sangat dibutuhkan bagi kepentingan umat manusia adalah narkotika. 
Salah satu persoalan besar yang telah dihadapi bangsa Indonesia pada umumnya saat ini adalah seputar maraknya penyalahgunaan narkotika dan obat-obatan berbahaya yang semakin hari semakin mengkhawatirkan. Jutaan orang telah terjerumus ke dalam lembah hitam narkotika dan ribuan nyawa melayang karena jeratan lingkaran setan bernama narkotika. Telah banyak keluarga yang hancur karenanya dan tidak sedikit pula generasi muda yang kehilangan masa depan karena perangkap yang disebut narkotika.

Menyimak perkembangan peredaran dan pengguna narkotika yang terus meningkat di Indonesia dari tahun ke tahun membuat hati kian miris. Coba tilik hasil surbei BNN (Badan Narkotika Nasional) dengan Universitas Indonesia dan juga Universitas lain. Tahun 2005 persentasenya 1,7 persen dari seluruh indonesia. Lalu tahun 2008 naik menjadi 1,99 persen. Kemudian tahun 2011 menjadi 2,2 persen dan diperkirakan hingga tahun 2015 terus naik menjadi 2,8 persen atau sekitar 5,8 hingga 6 juta jiwa. ${ }^{1}$ Badan Narkotika Nasional (BNN) Kota Palopo mencatat peredaran dan penyalahgunaan narkotika di Kota Palopo telah memasuki peringkat ke 6 (enam) di provinsi Sulawesi Selatan. Untuk mengantisipasi korban yang terus bertambah, oleh pihak BNN Palopo akan terus melakukan sosialisasi dan tes urine dilingkup pendidikan dan instansi pemerintah di Kota Palopo sebagai upaya pencegahan sejak dini. ${ }^{2}$

Kapolres Kota Palopo, AKBP. Muh.Guntur, melalui Kasat narkoba Kota Palopo AKP. Budi Gunawan, mengatakan peredaran dan pengguna narkotika di Kota Palopo mengalami peningkatan sepanjang tahun 2013 dibanding pada tahun 2012 yang lalu. Pada tahun 2013 sebanyak 15 kasus narkotika dan 21 tersangka yang telah di tangkap oleh jajaran Polres Kota Palopo. Ia menambahkan sementara pada tahun 2012 yang lalu, hanya sekitar 13 kasus narkotika di Kota Palopo dan 25 orang yang telah ditetapkan sebagai tersangka hingga akhir bulan desember. Dari 21 orang yang telah ditetapkan sebagai tersangka oleh Polres Kota Palopo, sebanyak 13 orang yang merupakan warga Kota Palopo. ${ }^{3}$

Beberapa penelitian tentang penanggulangan penyebaran narkoba telah dilakukan, diantaranya adalah skripsi yang berjudul "Penanggulangan Penyalahgunaan Narkotika Di Kalangan Remaja Dan Hubungannya Dengan Pendidikan Di Kotamadya Yogyakarta" yang ditulis oleh Yohannetta

1News Liputan6, http://news.liputan6.com/read/475553/kaleidoskop-6-catatankriminal-2012.(diakses tanggal 29 Maret 2016)

${ }^{2}$ Sawerigading News, http://sawerigadingnews.com/bnn-palopo-korban-penggunanarkotika-rehabilitasi-solusi-tepat/.(diakses tanggal 29 Maret 2016)

${ }^{3}$ Tribun Timur News, http://makassar.tribunnews.com/2013/11/01/waspada-kasusnarkoba-meningkat-di-palopo.(diakses tanggal 29 Maret 2016) 
Trismiyati dari Fakultas Pendidikan Ilmu Pengetahuan Sosial, IKIP Veteran Yogyakarta. Pada hasil penelitiannya menjelaskan bahwa dalam menangani masalah kenakalan remaja pada umumnya dan penyalahgunaan narkotika khususnya, masih ada beberapa hambatan yang menyebabkan kurang lancarnya usaha ini. Adapun hambatan itu misalnya :

a. Kurang adanya kesadaran masyarakat/orang tua bahwa sebenarnya narkotika hanya dapat diberantas atau ditanggulangi bila ada kerja sama dari berbagai pihak, di antaranya orang tua, masyarakat, dan pemerintah.

b. Sementara itu masyarakat biasanya tidak mau menerima kembali seseorang yang pernah terlibat dalam narkotika meskipun sudah sembuh setelah mendapat perawatan/terapi dan rehabilitasi, sehingga sering bekas pecandu narkotika ini merasa tersingkir dan tidak diterima kembali oleh masyarakat, akhirnya untuk mengobati kekecewaannya mereka ini lari lagi dalam penyalahgunaan narkotika. Itulah hambatan yang dialami dalam menanggulangi masalah narkotika. ${ }^{4}$

Penelitian lain dilakukan oleh Muhammad Ibnu, Penyalahgunaan Narkotika dan Cara Mengatasinya Pada Kalangan Remaja di Kota Palopo. Pada hasil Ibnu mengungkapkan bahwa yang menjadi faktor penyebab penyalahgunaan narkotika pada kalangan remaja di kota palopo adalah faktor diri, faktor lingkungan dan faktor ketersediaan narkotika dan yang menjadi hambatan dalam menanggulangi penyalahgunaan narkotika pada kalangan remaja di kota palopo adalah masih kurangnya minat remaja untuk mengetahui dampak negatif dari narkotika, masih rendahnya lembaga pendidikan menerapkan pola hidup sehat tanpa narkotika melalui penguatan kurikulum, dibutuhkan kerja sama yang baik antar orang tua dan pemerintah dalam memerangi penyalahgunaan narkotika pada kalangan remaja di kota palopo serta masih kurangnya kepedulian dan kerja sama masyarakat/instansi (pemkot) dalam melaksanakan program P4GN di kota palopo. Sehingga harapan penulis disini adalah Marilah bersama-sama mendukung program P4GN BNN kota palopo sehingga hasil penanggulangan penyalahgunaan narkotika bisa lebih efektif. ${ }^{5}$

Penelitian ini mencoba menggali kontribusi dakwah dalam membantu menanggulangi penyalahgunaan narkotika di kota Palopo. Secara terminologi dakwah berasal dari bahasa arab "da'wah. Da'wah mempunyai tiga huruf asal, yaitu $d a>l$, 'ayn, dan $w a>w$. Dari ketiga huruf asal ini,

\footnotetext{
${ }^{4}$ Yohannetta Trismiyati. Penanggulangan Penyalahgunaan Narkotika Di Kalangan Remaja Dan Hubungannya Dengan Pendidikan Di Kotamadya Yogyakarta. (Laporan Hasil Penelitian Fakultas Pendidikan Ilmu Pengetahuan Sosial, IKIP Veteran Yogyakarta. 1986).

${ }^{5}$ Muhammad Ibnu, Penyalahgunaan Narkotika dan Cara Mengatasinya Pada Kalangan Remaja di Kota Palopo, Skripsi (Palopo: IAIN Palopo, 2015), h. 10.
} 
terbentuk beberapa kata dengan ragam makna. Makna-makna tersebut adalah memanggil, mengundang, minta tolong, meminta, memohon, menamakan, menyuruh datang, mendorong, menyebabkan, mendatangkan, mendoakan, menangisi, dan meratapi. ${ }^{6}$ Yang menarik walaupun kata dakwah dari segi kosa katanya berbentuk ism (kata benda) namun dalam pengertiannya, karena termasuk diambil (mushtaqq) dari fi'l al-muta'addi, mengandung nilai dinamika, yakni ajakan, seruan, panggilan, permohonan (sebaimana disebutkan di atas). ${ }^{7}$

Makna tersebut mengandung unsur usaha atau dinamis. Terlebih jika merujuk kepada Alquran sebagai mas\}dar al-da'wah hampir semua yang ada kaitannya dengan dakwah diekspresikan dengan kata kerja (fi'l al-madi', fi'l al-mudhri', dan fi'l al-amr). Artinya, dakwah juga bermakna proses penyampaian pesan-pesan tertentu berupa ajakan, seruan, undangan, untuk mengikuti pesan tersebut atau menyeru dengan tujuan untuk mendorong seseorang supaya melakukan cita-cita tertentu. ${ }^{8}$

Ada beberapa pendapat ahli tentang makna dan definisi dakwah yang disebutkan oleh Enjang AS, diantaranya adalah ${ }^{9}$ :

1) Shaykh 'Alii Mahfuz, menyatakan bahwa dakwah adalah, "Sebagai upaya membangkitkan kesadaran manusia di atas kebaikan dan bimbingan, menyuruh berbuat makruf, dan mencegah perbuatan munkar supaya mereka mendapat kebahagian di dunia dan akhirat"

2) Dakwah yang menekankan kepada pengamalan aspek pesan dakwah, ini dikemukakan oleh Ibn Taymiyyah (1398 H), dan pesan dakwah yang terkandung dalam perspektif ini adalah: (1) Mengimani Allah; (2) Mengimani segala ajaran yang dibawa oleh semua utusan Allah; (3) Menegakkan dan mengikrarkan Shahadatayn; (4) Menegakkan salat; (5) Mengeluarkan zakat; (6) Berpuasa di bulan Ramad\}a>n; (7) Menunaikan ibadah haji; (8) Mengimani malaikat; (9) Menyerukan agar hamba Allah hanya beribadah kepada-Nya seakan-akan melihat-Nya. Satu perbedaan dalam definisi ini dengan definisi lainnya adalah pada penekanan aspek ih\}sa>n dalam

\footnotetext{
${ }^{6}$ Ahmad Warson Munawwir, Kamus Al-Munawwir (Jakarta: Pustaka Progressif,
} 1997), 406.

${ }^{7}$ Asep Muhyidin dan Agus Ahmad Safei, Metode Pengembangan Dakwah (Bandung: Pustaka Setia, 2002), 27. Lihat juga Abdul Aziz, Islah al-Wakhudu al-Diniy (Mesir: Attiqarah al-Kubra, 1997), 26.

${ }^{8}$ Ahmad Subandi, Ilmu Dakwah Pengantar ke Arah Metodologi (Bandung: Yayasan Syahida, 1994), 10. 2009), 6-14.

${ }^{9}$ Enjang AS dan Aliyudin, Dasar-Dasar Ilmu Dakwah (Bandung: Widya Padjadjaran, 
beribadah, yaitu sebuah proses yang menghendaki adanya kesadaran akan kehadiran Allah dan berprilaku dengan sebaik-baiknya.

Dari berbagai macam definisi yang di utarakan oleh para ahli, Ali Aziz mendefinisikan dakwah sebagai proses peningkatan iman dalam diri manusia sesuai sesuai syariat Islam. "Proses" menunjukan kegiatan yang terus-menerus, berkesinambungan, dan bertahap. Peningkatan adalah perubahan kualitas yang positif: dari buruk menjadi baik, atau dari baik menjadi lebih baik. Peningkatan iman termanifestasi dalam peningkatan pemahaman, kesadaran dan perbuatan. ${ }^{10}$

Dalam penelitian ini penulis lebih cenderung memilih makna dakwah yang ditawarkan oleh Ali Aziz, karena dakwah dalam hal ini sesuai dengan konteks debus yang merupakan sebuah proses kegiatan yang berkesinambungan yang bertujuan kepada peningkatan kualitas keimanan. Kata kuncinya adalah bahwa pembelajaran debus merupakan kegiatan yang terus menerus, berkesinambungan dan bertahap, dan tiap tahapan memiliki nilai dan proses dalam menghadirkan kepasrahan kepada Allah swt. Kare na pembelajaran debus hanyalah proses dari harapan para pelakunya untuk sampai kepada kemapanan iman yang dimanifestasikan dalam kepasrahan.

Dalam bahasa Arab media sama dengan wasilah (atau dalam bentuk jamak, wasail yaitu segala hal yang dapat menghantarkan tercapainya kepada sesuatu yang dimaksud. ${ }^{11}$ Ali Aziz mengartikan bahwa media dakwah adalah alat yang menjadi perantara penyampaian pesan dakwah kepada mitra dakwah. ${ }^{12}$ Sesuatu yang menjadi perantara penyampaian sebuah pesan kepada komunikan tentu tak terbatas hanya pada hal-hal yang bersifat material, namun ia juga dapat berwujud manusia, konsep, lembaga, kondisi tertentu, waktu tertentu dan lain sebagainya. Sebagaimana Asmuni membagi media dakwah menjadi beberapa bentuk: ${ }^{13}$
a. Lembaga-lembaga pendidikan formal maupun non-formal
b. Lingkungan keluarga
c. Organisasi-organisasi Islam
d. Hari-hari besar Islam
e. Media Massa
f. Seni budaya

\footnotetext{
10Moh. Ali Aziz, Ilmu Dakwah (Jakarta: Kencana Prenada Group, 2009), 19-20.

11Enjang AS dan Aliyudin, Dasar-Dasar Ilmu Dakwah.,h. 93.

12Moh. Ali Aziz, Ilmu Dakwah, h. 311

${ }^{13}$ Asmuni Syukir, Dasar-dasar Strategi Dakwah Islam (Surabaya: Al-Ikhlas, 1983),
} 168-180. 
Dalam hal ini Ali Aziz juga menambahkan, bahwa Media dakwah dapat berfungsi secara efektif bila ia dapat menyesuaikan diri dengan pendakwah, pesan dakwah, dan mitra dakwah. Selain ketiga unsur utama ini, media dakwah juga perlu menyesuaikan diri dengan unsur-unsur dakwah yang lain, seperti metode dakwah dan logistik dakwah. Pendek kata, pilihan media dakwah sangat terkait dengan kondisi unsur-unsur dakwah.

Unsur dakwah yang paling berpengaruh atas keberadaan media dakwah adalah pendakwah. Hampir semua media dakwah bergantung pada kemampuan pendakwah, baik secara individu maupun kolektif. Kemampuan pendakwah tidak hanya sebatas operasional media, tetapi juga pada pengetahuan dan seni dalam penggunaan media tersebut.

\section{METODE}

Jenis penelitian yang digunakan adalah penelitian kualitatif. Pendekatan yang digunakan dalam penelitian ini meliputi pendekatan sosiologis, dan teologis normatif. Pendekatan sosiologis yang bertujuan untuk melihat dan mengetahui kontribusi dakwah dalam mengantisipasi Narkoba di Kota Palopo, sedangkan pendekatan teologis normatif berfungsi sebagai pijakan dalam segala hal, yang tidak keluar dari al-Qur'an dan Hadis.

Sumber data primer penelitian ini berasal dari data lapangan yang diperoleh melalui wawancara terstruktur maupun tidak terstruktur terhadap informan yang berkompeten dan memiliki pengetahuan tentang penelitian ini. Adapun yang menjadi sumber data primer dalam penelitian ini adalah mereka yang biasa ikut terlibat dalam kegiatan pencegahan narkoba di Kota Palopo yaitu BNN (Badan Narkotika Nasional) Kota Palopo disamping itu dalam penelitian ini peneliti mengambil sumber data dari dari Polres Kota Palopo.

Metode pengumpulan data yang akan digunakan dalam penelitian ini adalah Interview (wawancara) wawancara terstruktur dan tidak terstruktur dengan menggunakan seperangkat instrumen penelitian berupa pertanyaanpertanyaan tertulis sebagai pedoman dalam melakukan wawancara, ataupun hanya berupa garis-garis besar permasalahan yang akan ditanyakan, ${ }^{14}$ baik kepada guru, siswa, dan siswi maupun informan yang dipandang mengetahui kondisi di lokasi penelitian. Agar data hasil wawancara tidak hilang, maka disamping melakukan pencatatan hasil pembicaraan juga menggunakan alat perekam.

Proses analisis data dilakukan melalui tiga tahapan secara berkesinambungan, yaitu reduksi data, penyajian data dan penarikan

${ }^{14}$ Sugiyono, Metode Penelitian Kuantitatif, Kualitatif dan R\&D, h. 138-140. 
kesimpulan. Tahap pertama adalah melakukan reduksi data, yaitu suatu proses pemilihan, pemusatan perhatian untuk menyederhanakan data kasar yang diperoleh di lapangan. Kegiatan ini dilakukan secara berkesinambungan sejak awal kegiatan hingga akhir pengumpulan data. Tahapan kedua adalah melakukan penyajian data. Maksudnya adalah menyajikan data yang sudah disaring dan diorganisasikan secara keseluruhan dalam bentuk naratif deskriptif. Dalam penyajian data dilakukan interpretasi terhadap hasil data yang ditemukan, sehingga kesimpulan yang dirumuskan menjadi lebih objektif. Tahapan ketiga adalah melakukan penarikan kesimpulan, yaitu merumuskan kesimpulan setelah melakukan tahapan reduksi dan penyajian data secara induktif untuk menjawab rumusan masalah. Untuk mengecek keabsahan data, dilakukan dengan membandingkan hasil pengamatan dengan hasil pengamatan berikutnya, serta membandingkan hasil pengamatan dengan hasil wawancara. Penekanan dari hasil perbandingan ini untuk mengetahui alasan-alasan terjadinya perbedaan data yang diperoleh selama proses pengumpulan data.

\section{KONTRIBUSI DAKWAH DALAM MENGANTISIPASI PENYALAHGUNAAN DAN PENGEDARAN NARKOBA DI KOTA PALOPO}

Dakwah jika dianggap sebagai suatu profesi tidak lagi dipandang dalam hati sempit dari sudut pandang tertentu seperti ceramah agama bi lisan saja melainkan mencakup makna lebih luas yang terkait erat dengan usaha pengembangan keagamaan dan merealisasikan ajaran Islam pada berbagai aspek dan lini kehidupan manusia. Aspek kehidupan manusia merentang dari persoalan keyakinan(teologi), ritual (ibadah), sosial ekomoni, budaya dan politik. Aspek kehidupan yang kompleks dan sistemik ini sesuai dengan cakupan ajaran Islam yang universal dan komprehensif. Dalam konteks inilah, ajaran islam yang multi dimensional menjadi pesan yang ditransformasikan ke dalam kehidupan nyata manusia melalui proses dakwah.

Dakwah dalam Islam adalah upaya untuk mengajak manusia ke jalan yang baik menurut ajaran Allah dan RasulNya. Upaya tersebut sesuai dengan kecenderungan atau fitrah manusia, karena itu panggilan dakwah adalah panggilan kemanusiaan. Namun demikian, ternyata tidak semua manusia yang diajak kejalan yang benar itu langsung direspon secara positif, hal yang demikian ini menunjukkan bahwa ada sesuatu yang tidak sinergik antara pelaku dakwah dengan sasaran dakwah. 
Narkoba dan obat-obat terlarang lainnya adalah salah satu sumber penyakit sosial di era globalisasi ini bahkan menjadi permasalahan yang sangat serius dan benar benar telah membahayakan bagi masyarakat dan bangsa Indonesia. Keberadaan narkoba membawa dampak so sial yang sangat berpengaruh, tidak hanya pada pemakainya tetapi juga pada masyakat banyak. Bahkan ia membawa dampak pada aspek hukum, pendidikan, kesehatan, psikologis dan agama. Sehingga persoalan ini harus dibicarakan secara integral dan komprehensif oleh banyak pihak.

Penyalahgunaan dan pengedaran narkoba akhir-akhir ini di Kota Palopo mengalami peningkatan dari tahu ke tahun hal ini dapat di lihat data yang ada di Badan Narkotika Nasional (BNN) Kota Palopo di tahun 2015 korban penyalahgunaan dan pengedaran narkoba baru angka puluhan yaitu 56 orang, tetapi pada tahun 2016 angka tersebut meningkat menjadi 139 orang korban peningkatan yang cukup signifikan. Untuk lebih jelasnya dapat dilihat data sebagai berikut :

\section{Tabel 1}

Korban Penyalahgunaan Narkoba di Kota Palopo

\begin{tabular}{|c|c|c|c|l|}
\hline IPWL & $\begin{array}{c}\text { RAWAT } \\
\text { JALAN }\end{array}$ & $\begin{array}{c}\text { RAAT } \\
\text { INAP }\end{array}$ & TAT & TAHUN \\
\hline 27 Orang & 14 orang & 4 orang & 11 orang & 2015 \\
\hline 69 orang & 31 orang & 6 orang & 16 orang & 2016 \\
\hline
\end{tabular}

Data tersebut menujukkan angka kenaikan yang signifikan. Dengan keyataan yang demikian itu tetu saja sangat meperihatinkan bagi kita semua termasuk para dai. Oleh karena itu dai sebagai penganjur kebajikan, amar ma'ruf nahi munkar harus memberikan kontribusi dalam mengantisivasi penyalahgunaan dan pengedaran narkoba tersebut.

Dai bertugas untuk megajak orang kepada jalan yang baik, jalan keselamatan, kepada Allah. Kontribusi yang telah diberikan oleh para dai dalam mengantisivasi penyalahgunaan dan pengedaran narkoba di Kota Palopo, secara umum dapat dilihat dalam penyampaian pesan-pesan agama yang dilakukan melalui berbagai bentuk, misalnya melalui khutbah setiap hari jumat, ceramah melalui peringatan hari-hari besar Islam, ceramah melalui majelis taklim, ceramah melalui perkumpulan atau jamaah yang melakukan acara shilaturrahim, pelajaran melali sekolah mulai dari tangkat yang terendah sampai kepada perguruan tinggi. Hal tersebut menunjukkan bahwa sesungguhnya dai telah berkontribisi dalam mengantisivasi penyalah gunaan dan pengedaran narkoba. 
Dai dalam menangani narkoba di kota Palopo, dai terbagi dalam beberapa kelompok yaitu kelompok BNN kota Palopo, kelompok ini adalah kelompok yang paling depan memerangi narkoba karena memang tugas pokok yang diberikan oleh Negara khusus untuk itu.

Langkah-langkah yang dilakukan oleh BNN kota Palopo dalam menangani narkoba adalah sebagai beribut:

\section{Memberikan penyuluhan;}

Penyuluhan dilakukan secara formal di sekolah-sekolah yang ada di wilayah Kota Palopo, kepada anak-anak sekolah mulai dari tingkat sekolah dasar, sekolah menengah pertama, sekolah menegah atas dan sampai kepada perguruan Tinggi. Mereka semuanya diberikan pemahaman tentang bagaimana bahayanya menyalah gunakan narkoba. Penyuluhan yang demikian ini berlangsung beberapa kali yang dilakukan di sekolah masingmasing dengan berbagai bentuknya. Khusus untuk perguruan tinggi dibuat dalam bentuk seminar tentang bahaya penggunaan narkoba secara illegal.

Bentuk penyuluhan ini diberikan pula kepada Ibu-ibu yang teragabung dalam kelompok majelis ta'lim yang ada di wilayah Kota palopo, mereka diberikan pemahaman tentang pentingnya menjaga generasi pelanjut terhadap penggunaan narkoba, karena kalau meraka suda terjerumus kedalam lembah kehinaan rasana sulit untuk dipulihkan. Karena itu sebelum mereka telibat harus benar benar digaja. Dengan demikian ibu-ibu rumah tangga adalah guru dan pengawas yang pertama di rumah tangga, meskipun demikian kebanyakan anak-anak yang terlibat dalam narkoba bukan diperoleh dari dalam rumahnya, tetapi diperoleh dari luar rumah sebagai akibat dari pergaulan bebas yang tidak terkonrol oleh orangtua di rumah. Jadi memang ibu-ibu rumah tangga sangat signifikan keterkaitannya dengan pencegahan narkoba. Dalam hal penyuluhan BNN Kota Palopo mengadakan MoU dengan Muaballigh Kota Palopo. ${ }^{15}$

\section{Pemantauan dan penangkapan}

Selain penyuluhan yang dilakukan oleh BNN Kota Palopo melaukan pemantauan dan pengangkapan baik terhadap pengguna maupun terhadap bandar-bandar yang ada. Bandar yang ada di Kota Palopo hanya Bandar kecil yang ada belum ada Bandar bersar menurut keterangan dari BNN Kota Palopo. Cara BNN melakukan pemantauan adalah dengan memperluas jaringan informasi tentang adanya pengedar, bandar dan pengguna narkoba. Bagi mereka yang benar-benar terbukti kedapatan menyalah gunakan

15Jufri Mustafa, Kasubag Tata Usaha,Wawancara, Badan Narkotika Nasional Kota Palopo, 28 November 2016 
narkoba baik selaku Bandar, pengedar dan pengguna mereka ditangkap oleh petugas yang berwewenang, kemudian dip roses sebagaimana mestinya. Untuk mengetahui apakah mereka benarbenar telibat dalam menyalah gunaan norkoba, maka kepad mereka dilakukan tes urin.

Selain mereka yang ditangkap melalui upaya penjaringan yang dilakukan oleh BNN ada juga yang datang secara suka rela melaporkan diri. Mereka yang sudah tertangkap baik melalui penjaringan maupun yang datang melapor secara suka rela, akan dilakukan pembinaan oleh BNN Kota Palopo.

Adapun macam-macam pembinaan yang dilakukan Oleh BNN Kota Palopo yaitu; Rawat inap, mereka dirawat dan menginap di tempat yang telah disediakan oleh BNN lalu dibina oleh TAT yaitu Medis, Hukum dan BNN dan konseling Sekolah. Selain Rawat Inap ada juga rawat jalan, rawat jalan itu dilakukan beberapa kali pertemuan biasanya 3 - 12 - 15 x pertemuan. Selain rawat inap dan rawat jalan masih ada rawat lanjut yang dilakukan di rumah korban, pihak BNN mendatangi rumah dan lingkunagnnya untuk melakukan perawatan selanjutnya.

Pada pasca rehabilitasi, yaitu setelah mereka dibina maka langkah selanjutnya adalah pengembalian fungsi so sial, biasanya dilakukan sebanyak 8 x pertemuan, Tujuanannya adala untuk mengembalikan mereka kepada fungisi sosialnya sebagai mana sebelumnya sehingga mereka benar-benar kembali kepada masyarakat tanpa menyimpan masalah yang akan mengganggu ketentraman dalam lingkunan hidup sosialnya. ${ }^{16}$

Inilah hal-hal yang dilakukan oleh BNN Kota Palopo dalam rangka menangani penyalah gunaan Narkoba di Kota Palopo.

Selain BNN Kota Palopo, juga dai kelompok kepolisian Polres Kota palopo. Adapun langkah-langkah yang dilakukan adalah melakukan penyuluhan terutama kepada anak-anak sekolah, bahkan yang dilakukan oleh pihak kepolisian dimulai dari tk. Dalam bentuk pengenalan kepada anak-anak usia dini, kemudian kepada anaka sekolah menengah pertama, menengah atas dan perguruan tinggi. Mereka melakukan penyuluhan memberikan pemahaman tentang bahaya yang akan ditimbulkan terhaqdap penyaalahgunaan narkoba, bukan saja membahayakan pelakukanya atau korbannya tetapi juga terhadap lingkungan sosial, karena memang narkoba itu adalah salah satu penyakit sosial yang sangat memperihatinkan karena dapat menyentuh segala lapisan masyarakat, bahkan lokasinya pun tidak

${ }^{16}$ Anneka Devy R, Pasilitator BNN Kota Palopo, Wawancara pada tanggal 29 November 2016, di BNN Kota Palopo 
hanya berada pada perkotaan tapi kini sudah merambah ke desa-desa terpencil sekalipun.

Selain melakukan penyuluhan kepada anak-anak sekolah juga kepada kelompok-kelompok majelis taklim dan kelompok generasi muda, semuanya bertujuan untuk memberikan pemahaman dan kesadaran masyarakat agar benar-benar memperhatikan secara serius tentang penyalah gunaan narkoba. Kepolisian Resort (POLRES) Kota Palopo telah melakukan berbagai aktivitas untuk mencegah dan menanggulangi penyalah gunaan norkoba, termasuk melakukan pemantauan dan penangkapan oknum-oknum yang ternyata telah terbukti menyalah gunakan narkoba baik selaku bandar, pengedar maupun pengguna.

Berbagai cara yang telah dilakukan termasuk dengan memberikan keringanan hukuman bagi mereka yang telah tertangkap oleh pihak kepolisian lalu memberitahu teman-yemannya yang lain yang diketahuinya melakukan hal yang sam. ${ }^{17}$ Aiptu Langkaryanto. Kontribusi yang diberikan oleh kelompok dai yang tergabung dalam ikatan muballigh Kota Palopo berupa ceramah dan khutbah dalam bentuk amar makruf nahi munkar, bentuk ini yang paling banyak dilakukan karena setiap waktu para dai atau muballigh senantiasa melaksanakan tugasnya sebagai penyampai pesanpesan Islam kepada seluruh umat manusia. Hal ini kelihatan dalam program imkot yang melaksanakan operasionalisasi dakwah di Kota Palopo. Apalagi di waktu-waktu tertentu seperti di bulan ramadhan semua masjid, mushalla bahkan tempat-tempat khusus dipenuhi dengan kegiatan-kegiatan ceramah, ini semua bertujuan untuk megajak manusia melakukan hal-hal yang positif dan menjauhi larangan-larangan Allah demi mencapai kemaslahatan hidup manusia.

Khusus yang terkait dengan masalah narkoba kelihatannya memang belum terlalu spesifik dibahas oleh para dai, ini dapat dilihat pada tema-tema yang telah disampaikan oleh para dai setiap memberikan ceramah belum banyak yang secara khusus membicarakan masalah narkoba, padahal masalah tersebut sangat penting karena masalah itu semakin hari semakin menujukkan peningkatan, meskipun harapan adalah penurunan, tetapi kenyataannya justru meningkat, seperti data yang telah dikemukakan di atas bahwa pada tahun 2015 yang lalu jumlah korban narkoba di Kota Palopo yaitu 56 orang namun pada tahun 2016 justru meningkat menjadi 139 orang, suatu peningkatan yang cukup signifikan.

Menyikapi kondisi tersebut, mestinya peranan para dai terutama yang tergabung dalam organisasi dakwah semakin ditingkatkan dengan berbagai

\footnotetext{
${ }^{17}$ Langkaryanto, Bagian Narkoba Polres Palopo, wawancara pada tanggal 25 November 2016 di Polres Palopo
} 
cara demi tercapainya tujuan pemberantasan dan penggagalan narkoaba di Kota Palopo. Kalau selama ini para dai di Kota Palopo dalam memberantas narkoba masih bersifat umum, maka mestinya lebih dikembangkan lagi menjadi dakwah spesifik tentang narkoba agar lebih efektif.

Agar dakwah lebih langsung terasa kepada para penyalahguna narko ba maka sebaiknya dakwah yang dilakukan oleh para dai tidak menoton pada bentuk ceramah tetapi pada aksi-aksi yang dapat dirasakan langsung oleh korban narkoba. Misalnya upaya peningkatan ekonomi uamat, karena salah satu penyebab terjadinya penyalah gunaan nokoba adalah masalah eko nomi.

\section{METODE DAKWAH DALAM MENGANTISIPASI PENGEDARAN DAN PENYALAHGUNAAN NARKOBA DI KOTA PALOPO.}

Dakwah dalam Islam adalah upaya manusia untuk mengajak sesama manusia kepada jalan yang benar yang diridhai oleh Allah Swt. yang tujuannya adalah untuk mencapai kemaslahatan hidup manusia di dunia dan di akhirat. Karena itu, berdakwah dalam Islam adalah kewajiban bagi setiap muslim yang sudah mukallaf. Karena itu setiap muslim harus melakukan dakwah yakni mengajak manusia kepada yang baik dan melarang manusia melakukan hal-hal yang buruk, yang dalam bahasa dakwah yaitu; amar makrufnahi munkar.

Berdakwah dalam Islam memiliki cara-cara yang baik, tidak asal berdakwah tetapi harus dilakukan dengan cara-cara yang baik yang dapat diterima oleh sasarannya. Cara-cara penyampaian pesan dakwah yang baik sangat diperlukan karena tidak semua yang baik itu disampaikan kepada orang pasti diterima juga dengan baik, seringkali terjadi justru kebajikan yang disampaikan ditolak bahkan ditantang oleh penerimanya karena cara penyampaiannya yang tidak tepat, di sinilah letak pentinnya motode atau cara-cara yang baik dilakukan dalam mengajak orang kepada kebaikan.

Adapun Metode Dakwah dalam mengantisifasi pengedaran dan penyalahgunaan Narkoba di Kota palopo;

1. Metode Ceramah;

Metode ceramah adalah salah satu metode dakwah yang masih relevan untuk dijadikan sebagai salah satu cara menyampaikan pesan-pesan dakwah. Dengan melalui ceramah pesan-pesan atau ajaran-ajaran agama mengenai berbagai aspek kehidupan manusia agar mencapai kemaslahatan hidupnya.

Para dai dalam menyampaikan atau menyeru manusia kepada jalan yang baik melakukan banyak ceramah-ceramah dalam berbagai pertemuan, 
terutama di masjid-masjid pada bulan ramadhan semua masjid dan mushalla dipenuhi oleh para dai dari berbagai latar belakang dan disiplin ilmu masing masing untuk memberikan pemahaman kepada masyarakat tentang apa yang harus dilakukan dan apapula yang harus ditinggalkan. Metode ceramah ini masih dianggap relevan karena melalui ceramahlah mereka yang tidak sempat menuntut ilmu secra formal di sekolah dapat menambah ilmu pengetahuan mereka. Itulah sebabnya metode ceramah ini masih dianggap efektif. Melalui ceramah yang dilakukan oleh para dai masyarakat akan tahu tentang bahaya yang ditimbulkan oleh narkoba, melalui ceramah orang akan tahu apa dampak atau efek narkoba dan lain-lain.

Meskipun demikian ceramah tentu saja tidak cukup, karena tidak semua masyarakat selau memilki waktu yang cukup untuk datang mendengarkan ceramah di suatu tempat. Karena itu, dakwah sebaiknya mencari bentkl lain dalam memecahkan berbagai problem sosial yang semakin hari semakin meningkat. Misalnya untuk kalangan perguruan tinggi khususnya di Kota Palopo terdapat banyak perguruan tinggi yang ada menampung mahasiswa yang cukup banyak jumlahnya, tentu saja lebih menarik jika dalam menyoal penyalahgunaan dan pengedaran narkoba di Kota Palopo dilakukan dialoh-dialoh ata diskusi untuk mencari solusi bagaiman mengatisifasi penyalahgunaan dan pengedaran narkoba. Hal ini belum banyak dilakukan oleh para dai yang ada di Kota palopo ini.

Selain metode tersebut dakwah juga dapat dilakukan dengan metode tanzir atau memeri peringatan berupa ancaman terhadap pelaku penyalahguna dan pengedar narkoba. Metode ini kadangkala menjadi epektif karena kenyataannya memang ada juga orang yang akan sadar setelah mendengarkan atau memperoleh ancaman atau sanksi yang diberikan kepada pelakunya. Bahkan ada juga yang sudah diberi sanksi justru melakukan lagi. Metode pemberia sanksi ini telah dilakukan oleh pihak yang berwewenang sperti dari BNN dan Kepolisian.

Judulnya disesuaikan dengan redaksi/deskripsi rumusan masalah yang dimaksud. Bagian ini berisi hasil penelitian dan pembahasan terkait dengan rumusan masalah pertama.. Pada hasil penelitian terlebih dahulu paparkan hasil penelitian yang telah diperoleh tanpa menyertakan deskripsi hasil pemikiran penulis atau tinjauan pustaka. Pada bagian pembahasan berisi tentang penjelasan hasil penelitian dikaitkan dengan rumusan masalah dalam penelitian, interpretasi hasil penelitian, serta membandingkan atau mengaitkan hasil penelitian dengan teori yang dirujuk.

\section{PENUTUP}

Berdasarkan pembahasan sebelumnya maka dapat disimpulkan: 
1. Dakwah adalah upaya yang dilakukan secara sadar untuk mengajak manusia kepada jalan yang baik dan benar yang bertujuan untuk mencapai kemaslahatan hidup di dunia dan di akhirat kelak. Pelaku dakwah dalam Islam disebut dengan istlah dai atau muballigh, mereka itu adalah orangorang yang selalu melakukan atau mengaja orang lain untuk melakukan sesuatu yang baik dan mealarang untuk melakukan yang tidak baik ( $m a^{\prime}$ ruf nahi munkar). Dengan demikian yang daimaksud dai dalam penelitian ini bukan saja kelompok muballigh secara professional, tetapi semua yang selalu mengajak kepada kebajikan dan melarang kepada kemungkaran, termasuk yang melarang menyalahgunakan dan mengedarkan narkoba.

2. Metode dakwah yang dilakukan oleh para dai dalam mengantisifasi penyalahgunaan dan pengedaran narkoba adalah dengan melakukan penyuluhan, ceramah-ceramah melalaui berbagai kelompok masyarakat, terutama kelompok anak sekolah mulai dari usia dini sampai kepada perguruan tinggi dan kelompok-kelompok sosial lainnya.

Adapun saran penelitian adalah:

1. Kepada pihak BNN serta Polres Palopo agar selalu melakukan sosialisasi terhadap dampak penyalahgunaan narkoba

2. Kepada pihak BNN serta Polres Palopo agar senantiasa melakukan pembinaan terhadap korban narkoba sehingga pelaku tidak dapat dibatasi ruang geraknya.

3. Kepada pihak BNN agar melakukan kerjasama dengan para dai dan konselor dalam rangka pembinaan korban narkoba

\section{DAFTAR PUSTAKA}

al-Qaradhawi. Yusuf, khithabuna Al-Islami fi Ashr Al-Aulamah. Diterjemahkan oleh Abdillah Noor Ridlo dengan judul retorika Islam bagaimana seharusnya menyampaikan wajah Islam. Jakarta :Pustaka Al-Kautsar, cet I .

News Liputan6, http://news.liputan6.com/read/475553/kaleidoskop-6catatan-kriminal-2012.

Undang-Undang Narkotika \& Psikotropika. Jakarta: Sinar Grafika, 2003

Sawerigading News, http://sawerigadingnews.com/bnn-palopo-korbanpengguna-narkotika-rehabilitasi-solusi-tepat.

Tribun Timur News, http://makassar.tribunnews.com/2013/11/01/waspadakasus-narkoba-meningkat-di-palopo.

Trismiyati. Yohannetta. Penanggulangan Penyalahgunaan Narkotika Di Kalangan Remaja Dan Hubungannya Dengan Pendidikan Di Kotamadya Yogyakarta. Laporan Hasil Penelitian Fakultas Pendidikan Ilmu Pengetahuan Sosial, IKIP Veteran Yogyakarta. 1986. 
Ibnu. Muhammad, Penyalahgunaan Narkotika dan Cara Mengatasinya Pada Kalangan Remaja di Kota Palopo, Skripsi. Palopo: IAIN Palopo, 2015.

Munawwir. Ahmad Warson, Kamus Al-Munawwir. Jakarta: Pustaka Progressif, 1997.

Muhyidin. Asep dan Agus Ahmad Safei, Metode Pengembangan Dakwah (Bandung: Pustaka Setia, 2002), 27. Lihat juga Abdul Aziz, Islah alWakhudu al-Diniy. Mesir: Attiqarah al-Kubra, 1997.

Subandi. Ahmad, Ilmu Dakwah Pengantar ke Arah Metodologi. Bandung: Yayasan Syahida, 1994.

AS. Enjang dan Aliyudin, Dasar-Dasar Ilmu Dakwah. Bandung: Widya Padjadjaran, 2009.

Ali Aziz. Moh, Ilmu Dakwah. Jakarta: Kencana Prenada Group, $2009 .$.

Syukir, Asmuni, Dasar-dasar Strategi Dakwah Islam. Surabaya: Al-Ikhlas, 1983.

Badan Narkotika Nasional, Petunjuk Teknis Advokasi Bidang Pencegahan Penyalahgunaan Narkoba Bagi Masyarakat Umum. Jakarta Timur: BNN RI,2012.

Sasangka. Hari, Narkotika dan Psikotropika Dalam Hukum Pidana. Bandung: Mandar Maju, 2003.

Undang-Undang Narkotika \& Psikotropika. Jakarta: Sinar Grafika, 2003.

Poerwadarminto, Kamus Umum Bahasa Indonesia. Jakarta: Balai Pustaka, 1985.

Dirdjosisworo. Soedjono, Kriminologi. Bandung: Bunga Rampai, 1985. , Narkotika dan Remaja. Bandung: Alumni, 1989.

S. Nasution,Metode Penelitian Naturalistik Kualitatif. Bandung: Tarsito, 1996.

Moleong. Lexy J., Metodologi Penelitian Kualitatif. Bandung: PT. Remaja Rosda Karya, 1995.

Hermawan Wasito, Pengantar Metodologi Penelitian, (Jakarta: Gramedia Pustaka Utama, 1995.

Warsito. Hermawan, Pengantar Metodologi Penelitian: Buku Panduan Mahasiswa. Cet. I; Jakarta: PT. Gramedia Utama, 1997.

Nawawi. Hadari dan Mimi Martini, Penelitian Terapan. Yogyakarta: Gajah Mada University Press, 1996.

Sugiyono, Metode Penelitian Kuantitatif, Kualitatif dan R\&D. Cet. XI; Bandung: Alfabeta, 2010.

Suprayogo. Imam, Metodologi Penelitian Sosial Agama. Cet. I; Bandung: Remaja Rosdakarya, 2001.

Subagyo. Joko, Metode Penelitian dalam Teori dan Praktek. Jakarta: Rineka Cipta, 1991.

S. Nasution, Metode Research(Penelitian Ilmiah). Cet. VIII; Jakarta: Bumi Aksara, 2006. 
194 | Masmuddin, Syahruddin

Usman. Husaini dan Purnomo Setiady Akbar, Metodologi Penelitian Sosial. Cet. III; Jakarta: Bumi Aksara, 2009.

Suprianto. J, Metode Riset Aplikasi dalam Pemasaran, Edisi 6. Jakarta: Fakultas Ekonomi, 1997. 